\title{
FDPS wt Allele
}

National Cancer Institute

\section{Source}

National Cancer Institute. FDPS wt Allele. NCI Thesaurus. Code C118211.

Human FDPS wild-type allele is located in the vicinity of $1 \mathrm{q} 22$ and is approximately $12 \mathrm{~kb}$ in length. This allele, which encodes farnesyl pyrophosphate synthase protein, is involved in isoprenoid biosynthesis. 